\title{
Adab sākhir (Satirical Literature) and the Use of Egyptian Vernacular
}

\author{
Eva Marie Håland
}

There were few, if any, bookstores in Cairo that did not, in 2013, have a section designated to a category of books labelled adab sākhir. Their titles play on humor and familiar Egyptian references; they are often in the vernacular 'àmmiyya - and sometimes repeated in 'Franco-Arabic'. In 2014, I was told that $a d a b s a \bar{k} h i r$ was a popular genre in the years leading up to the 2011 revolution, and right after it, but that there seemed to be a growing interest for different types of novels. ${ }^{1}$ The new wave of adab sākhir in Egypt did perhaps reach a 'peak' a few years ago, as Jacquemond (2016:356) reports that it meets competition from other "genres of 'popular' literature" such as romance and horror.

Nonetheless, the (re)emergence of this genre and the tendency for it being written entirely or partly in the vernacular is worth some focus. In this chapter, I will present some ways in which the Egyptian vernacular ('ämmiyya) and Standard Arabic ( fuṣhā) are used in adab sākhir, based on 21 books published between 2011 and 2014, as well as some motivations for using 'āmmiyya, as presented by writers. First, we will take a look at what lies in the label which these books have been given.

\section{Al-adab al-sākhir}

The notion adab sākhir appears to have come in use relatively recently, although Jacquemond argues that this type of literature has "ancient roots" (2008:155). He translates adab sākhir with 'satirical' (2008) or 'satiric' literature (2016), whereas Woidich (2010:81) uses the translation "satirische" or "sarkastische Literatur". In his article about medieval satire in Arabic literature, van Gelder (1998:693), says that "[t]here is no exact equivalent in Arabic for 'satire"” and " $[\mathrm{t}] \mathrm{o}$ some extent, therefore, speaking of satire in Arabic literature is to

1 Muṣțafā al-Faramāwī, Purchasing Manager of Shorouk Bookstores, personal interview, April 2014, Cairo. 
impose a Western concept on a tradition that has its own system of modes and genres". Van Gelder speaks of sukhriyya as "derision", and that sukhriyya and tahakkum "may be found as the nearest term for 'irony', although he points out that there is no equivalent for irony in Arabic literature either. This being said, van Gelder (1998:693) does say that "there is a considerable body of classical Arabic texts that may be called satirical."

Until recently, adab sākhir has not received much attention from scholars or critics. According to Jacquemond (2008:155), this is because it is "too hybridized to interest the folklorists and too 'low' to retain the interest of the legitimate criticism". He describes it as a kind of literature that "has an uncertain status somewhere between fiction and nonfiction, journalism and literature, and writing and orality" (Jacquemond 2008:155).

The Egyptian scholar Nabīl Rāghib (2000) explains sukhriyya as follows (2000: 13):

Sukhriyya in literature is the element that contains a dramatic mixture of criticism (نقد), derision (الهجاء), allusion (التلميح), insinuation (النماء), (المجاحية), mockery (التهك) and funmaking (الدعابة), for the purpose of exposing a person, concept, idea or whatever, and laying it bare by throwing light on its cracks (ثغرات) and its negative and deficit aspects. Thus, the primary goal of adab sākhir is correctional (تصحيحي), either on the moral (أخمات) (أخلاقي) or aesthetic (جمالي) level, and it differs in tone and manner from all other ways of expression that aim to reject, condemn or belittle the subject targeted by the writer or speaker.

The definition of 'Satire' provided by Britannica Online Encyclopædia (Elliott 2007) does not differ substantially from the one provided by Rāghib:

Satire, artistic form, chiefly literary and dramatic, in which human or individual vices, follies, abuses, or shortcomings are held up to censure by means of ridicule, derision, burlesque, irony, parody, caricature, or other methods, sometimes with an intent to inspire social reform.

Răghib (2000) explains that there is a difference concerning the notion adab sākhir as a comprehensive notion (كفهوم شامل), and sukhriyya as a literary device. He claims that "when sukhriyya becomes the fundamental element in the content, the spine for the events and scenes, then the work joins under 
the banner of adab sākhir" (Rāghib 2000:9). He goes through the centuries and dynasties in which satirical poets have used sukhriyya in poetry, and the blooming of the 'satirical press' that started in the end of the 19th century, with Ya'qūb Șannū' (1839-1912) and 'Abdallāh al-Nadīm (1845-1898) playing important roles. After the $195^{2}$ revolution, however, satirical writing almost disappeared in Egypt, due to a climate where criticism of the leader was much less tolerated (Rāghib 2000:37):

sukhriyya disappeared, or almost, from the pages of the newspapers and magazines. It became limited and directed at those people whom the leader (الزعيم) attacked in his speeches, or in his guidelines (توجيهات) to the media leadership. The satire no longer came from the thoughts and conscience of the writer, but rather became state-directed (موجهة), as any other political or commercial activity, so it lost its brilliance, sharpness and cheerfulness. The writers knew very well that whoever makes his satire cross fixed and drawn borders, in front of him is nothing but prison, expulsion or at the best prohibition from writing. The space for satire faded out (تضاءلت from the pages of the newspapers and magazines until only scattered fragments from Maḥmūd al-Sa'danī, Aḥmad Bahgat and Ahmad Ragab was left.

Referring to the 'big' writers within adab sākhir in Egypt, the names that generally come up are precisely Aḥmad Ragab (1928-2014), Maḥmūd al-Sa'danī (1928-2010) and Ahmad Bahgat (1932-2011), as well as Galāl 'Āmir (1952-2012), Muhammad 'Afífì (1922-1981) and 'Abbās al-Aswānī (1925-1977). The term adab sākhir was perhaps coined during their period of writing: the earliest use of the term that I have come across, is by Luwīs 'Awad in his foreword to Ahmad Bahgat's (2009) مذكرات زوج (Memoirs of a husband), which was probably published in its first edition in the beginning of the 1980 s. $^{2}$ Here, 'Awad claims that al-adab al-sākhir is the 'legitimate son' of adab al-hijä, ${ }^{3}$ and the 'cousin' of al-adab alfukāhì (humorous literature) (Bahgat 2009:6). The first direct labelling (on the cover) of a publication as adab sākhir that I have found is a 1997 edition of the book تحتمس ••؛ بشرطة (Thutmose 400 with a hyphen)4, also by Aḥmad Bahgat.

2 The 2009 edition informs that the third edition was published in 1986.

3 Invective or satirical poetry.

4 From the bus-system in Egypt where a stroke (sharța) through the bus number indicates a variation in the route (see Badawi and Hinds 1986, b ش ش). 


\section{Adad sākhir and the Vernacular}

Some of the early works that Rāghib mentions have been written at least partly in the vernacular, such as نزهة النفوس ومضحك العبوس (The Pastime of Souls, Bringing a Laugh to a Scowling Face) by Ibn Sūdūn and Yūsuf al-Shirbīnīs هز القحوف في شرح قصيد أبي شادوف Brains Confounded by the Ode of Abū Shādūf Expounded). ${ }^{5}$ Big parts of the satirical newspapers were also written in the vernacular, ${ }^{6}$ although not without controversy. According to Fahmy (2011:34), "[a] lmost all the colloquial content of these newspapers was satirical or humorous, primarily because the everyday vernacular was more suited to comedy and satire than Fusha". Fuṣhā was "considered too serious for effective satire" (Fahmy 2011:81). However, 'Abdallāh al-Nadīm was not an advocate of introducing 'ammmiyya for written purposes, but was rather concerned with education and political agitation (Woidich 2010).

From a look at a small sample of 6 adab sākhir publications from 1980s and 9os, two by Aḥmad Bahgat, two by Aḥmad Ragab and two by Maḥmūd al-Sacdanī, I have not found any noteworthy use of 'ammiyya in the narrative parts, only in dialogues and proverbs. (However, in Rosenbaum's (2000) article about the Fuṣhāmmiyya style, he gives an example from the writings by al-Sa'danī). A closer look at these satirical writers' language is necessary to understand better the relationship between satirical writing and use of 'āmmiyya.

\section{Adab sākhir Today - Satire or Pure Humour?}

The adab sākhir books in my study focus on different aspects of Egyptian society: as several were published not long after the $25^{\text {th }}$ of January revolution, it is an important subject, or at least receives some attention, in several of the publications. Another popular issue is the relationship between man and woman, and challenges with regard to finding a suitable match, and after finding it, spending everyday life with him or her, and perhaps adding another wife to the family.

In one way or another, all these books address challenges or peculiarities of the Egyptian society in a humorous way. Some of the issues raised are sensitive, and perhaps even taboo, and referred to as difficult or unsuitable to discuss in

\footnotetext{
5 See Davies (1981, 2000, 2005) and (Doss and Davies 2013).

6 See Zack (2014) for a description of use of the vernacular in Abu Naḍḍāra Zar’a.
} 
'serious writing' (kitāba gādda). Authors then choose to take to adab sākhir, where they can, as the 'satirical writer' İhāb Mu'awwad puts it, "wrap the serious subject in some nice paper and humour (damm khafif)" (Mu'awwad 02.09.2014).

Although adab sākhir has become the established label, some prefer kitāba sākhira, (satirical writing), rejecting it having the status of adab (literature). As Woidich (2010:83) mentions, there appears to be a common point of view among critics and publishers that much of what is published now is not 'real' adab sākhir. In an article in the magazine Rüz al-Yüsuf (Lu'ay 18.10.2009), several persons from the literary field comment on the blooming of adab sākhir literature, making statements such as the following by Muhammad 'Ilīwa:

The books that are published now, and on whose covers they write ' $a$ dab sākhir', most of them do not belong to the adab sākhir at all, but are rather an insult to it (إساءة له)

The critic Ahmad Darwīsh says that "real satirical writing is a kind of good literature that people need in certain periods in history, as a kind of safe opposition". He also calls adab sākhir "a refined and legitimate literary genre". At the same time, Darwīsh says that "what we see now, is false (زائفة) satirical writing". Authors and publishers are accused of taking advantage of the renewed popularity of the genre, and for using the label for texts that do not qualify for it. Darwish's perception of adab sākhir being a type of literature that is needed in certain periods seems to be shared by several in the literary sphere of Cairo; ${ }^{7}$ it is claimed that the recent social and political situation in Egypt has created a need for light and humorous literature where criticism can be expressed in a somewhat disguised manner.

The publisher and novelist Makkāwī Sa īd, on the other hand, although not in favour of publishing adab sākhir, sees one bright spot with the new trend. He thinks that as long as it is popular and encourages people to start reading, it can serve the role as the first step on a reading ladder.

On the website بص وطل (See and look) (14.11.2010), four contemporary writers referred to as 'satirical writers' are interviewed: Bilāl Faḍl, 'Umar Țāhir, Mușțafā Shuhayb, and Tāmir Aḥmad. Faḍl and Ṭāhir say that they are not in favour of labelling literature as sākhir or not sākhir. According to Țāhir, the

7 As was discussed in a seminar entitled الأدب الساخر .. موجات انحسار و صعود (Satirical literature ... waves of decline and rise) at Cairo International Book Fair 2015. 
readers have constructed a 'trap' ( $\dot{\mathcal{C}})$, by expressing that sākhir is what they want, making writers twist their arms to produce what the readers ask for. Shuhayb and Ahmad see that there are two types or schools within satirical writing: "laugh(ter) (ضحك) for the purpose of laughter, and laughter in order to achieve a goal (الضحك لتحقيق هدف), and that is the difference, whether laugher is the goal or the means". Muștafāa Shuhayb's comment is in line with Tāmir Ahmad's: "[...] one school that deals with societal issues and uses satire (سخرية) as a tool to discuss phenomena and problems, and another school that uses satire just for the satire. I think it depends on the humor (الإفيه) more than subject, and that its goal is entertainment".

It appears that the notion adab sākhir today is used to describe humorous texts, whether satirizing and moralizing with a correctional goal, or simply 'lighter' humour, where the goal is solely entertainment, unlike earlier, when negative aspects of society were always the target of satire. Guth (forthcoming 2017) suggests that "the most adequate rendering of the emerging generic term 'adab sākhir is perhaps 'carnivalesque literature' or 'subversive literature'". Jacquemond suggests a "more nuanced reading", as "oscillating between reformism and subversion” (2016:359).

\section{The Material}

Through a larger research in progress where I analyse language pattern choices in a comprehensive, but random sample of books published between the years 2011 and 2014 by Egyptian authors, it is clear that the books classified as adab sākhir distinguish themselves from novels and short story collections in containing larger amounts of 'ämmiyya.

The classification of the books as adab sākhir in this study is based on 'direct' and 'indirect' labelling of the books: The books that are 'directly' labelled have the label sākhir, maqālāt sākhira (satirical articles) or (min) (al-)adab sākhir on the cover, colophon or title page. ${ }^{8}$ The books that are 'indirectly' labelled may be described as kitāb sākhir on the back cover text. ${ }^{9}$ They can also be indirectly labelled in the text itself, such as in إشتري مني (Buy from me), where a hypothetical person asks Du'ā' Fārūq (2012:10):

8 al-Isīlī (2011), Ḥasan (2011), 'Abd al-Wahhāb (2013), Aḥmad (2012b), al-Inkishārī (2012), Macāṭ̄ (2013).

9 Shuhayb (2013), Galāl (2013). 


$$
\text { حاشرة نفسك ليه بتى في الكتب والأدب الساخر والجو ده؟ }
$$

Why do you get yourself into books and adab sākhir and those things?

Or such as by Shādī Aḥmad (2013:27) in مصر لامؤاخذة, in his list of advice on what to do when bored or sad:

$$
\begin{aligned}
& \text { جيب كتب ساخرة .. للكاتب شادي أحمد، وبالذات الحاجة دي هتفرحك قوي، وتفرح } \\
& \text { الكاتب، وهيدعيلك وهيخلي والدته تدعيلك (ومن قدم شيء بيداه التقاه). }
\end{aligned}
$$

Get hold of satirical books ... by the writer Shādī Aḥmad, and that in particular will make you very happy, and make the writer happy, and he will pray for you and let his mother pray for you (give, and you will receive).

Some books are not labelled adab sākhir neither in the text or paratext; they may, however, be featured or referred to as such, e.g. on the book-site Goodreads, in author interviews, on Facebook or other arenas where the book is promoted. ${ }^{10}$ It should also be noted that some of the authors of these books try to avoid categorization, as adab sākhir or as anything else, and that they may not agree to the label their book is given."

When it comes to text types, the adab sākhir books of this decade do not represent one specific text type. They are hybrid and diffuse, reminiscent of Elsadda's (2010:328) description of literary blogs: they

defy generic classification: they are invariably a mélange of diaries, memoirs, autobiographical stories, to-do shopping lists, political manifestos, reflections, epistolary narratives, short stories and novels.

The adab sākhir publications in the corpus also contain articles (maqūlāt), and poetry, as well as graphic elements such as caricatures and photographs. For an analysis of the forewords (muqaddimāt) of some of these books, see Guth (2017 Forthcoming).

10 al-Barbarī (2012) is directly labelled كناب كوميدي ثائر (Comical rebellious book).

11 See interview from بص وطل (See and look) referred to above. 
TABLE 6.1 List of corpus books

$\begin{array}{lll}\text { Author and year Title } & \text { Translation of title }\end{array}$

Du'ā' Fārūq (2012)

Muḥammad Nāgī (2013)

Aḥmad al-'Isīlì (2011)

Muḥammad Galāl (2013)

Jihād al-Tābi'ī (2012)

'Abīr 'Abd al-Wahhāb (2012)

Īhāb Mu'awwaḍ (2012)

Shādī Aḥmad (2012b)

'Amr al-Inkishārī (2012)

Maḥmūd Ḥasīb (2012)

Muḥammad Ḥasan (2011)

Muṣṭafā Shuhayb (2013)

Tāmir Aḥmad (2012c)

Mușțafā al-Barbarī (2012)

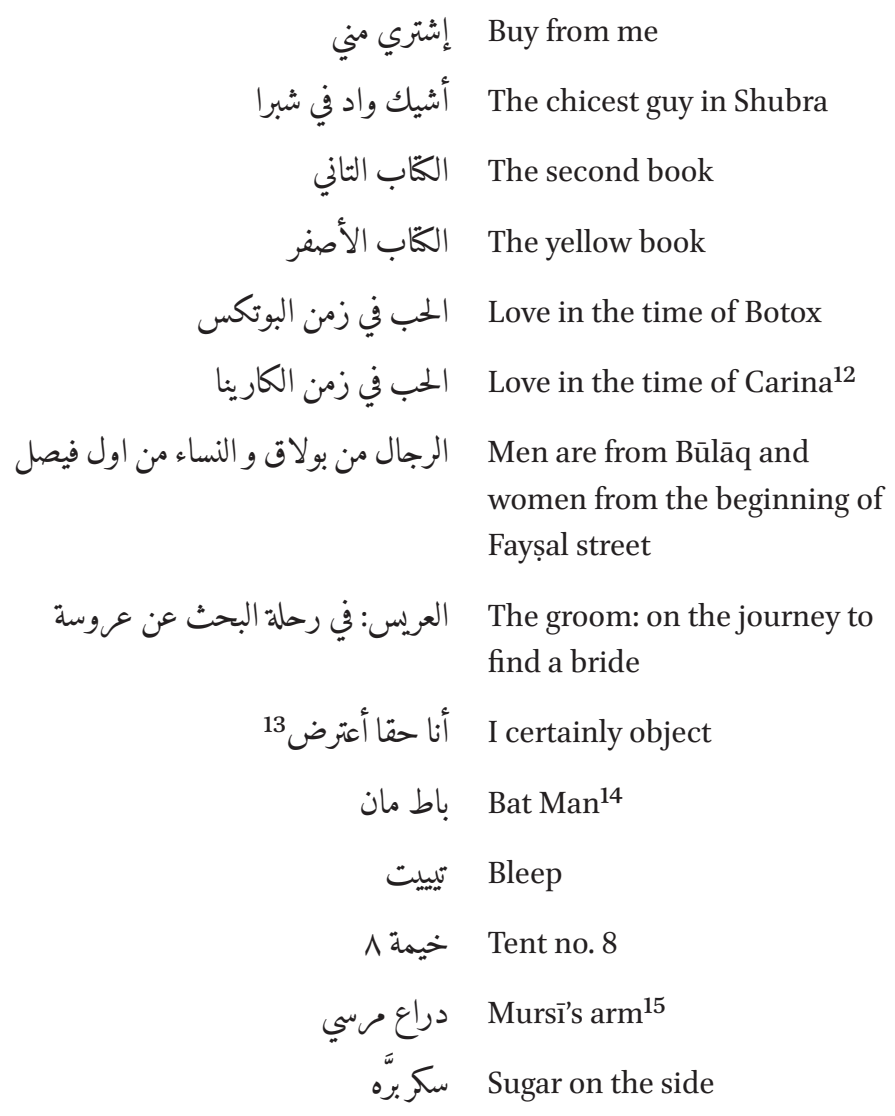

12 Carina (كارينا) is an Egyptian bodywear brand for women, and has become a proprietary eponym referring to any type of bodywear for women (especially long sleeves and tights covering the skin).

13 The abbreviation of this title makes the swear-word أحسا, which is used frequently in the text with reference to the title, but as أح أ أباط

14 The title is also a play on the word باط (armpit) instead of which is the common way of transcribing "Batman". The expression تحت الباط (under the armpit) is often used in the meaning "to control".

15 From the play مدرسة المشاغبين (The School of Troublemakers). 
TABLE 6.1 List of corpus books (cont.)

\begin{tabular}{|c|c|c|}
\hline Author and year & Title & Translation of title \\
\hline 'Abīr 'Abd al-Wahhāb (2013) & سواقة بنات: أبو اللّي علهُوا السواقة & $\begin{array}{l}\text { Girls' driving: damn (father } \\
\text { of) the one who taught you } \\
\text { how to drive }\end{array}$ \\
\hline Rīhām Magdī (2013) & شعب آخر 25 حاجة كمان وكمان & $\begin{array}{l}\text { A very } 25^{\text {th }} \text { people, again and } \\
\text { again }^{16}\end{array}$ \\
\hline Lubnā Imbārik (2013) & طاجن تورلي بالمحمة & Stew with meat \\
\hline Yūsuf Macāṭī (2013) & لقد وقعنا في الفخ & We fell into the trap ${ }^{17}$ \\
\hline Shādī Aḥmad (2013) & مصر لامؤاخذة & Pardon me, Egypt ${ }^{18}$ \\
\hline Shaymā’ Ḥabīb (2013) & المعجم الوجيز في تلخيص البهاريز19 & $\begin{array}{l}\text { The concise dictionary of } \\
\text { excerpting the essence }\end{array}$ \\
\hline Dīnā Ādil (2012) & ولاد البطة السودا & Children of the black duck \\
\hline
\end{tabular}

\section{Language Choices}

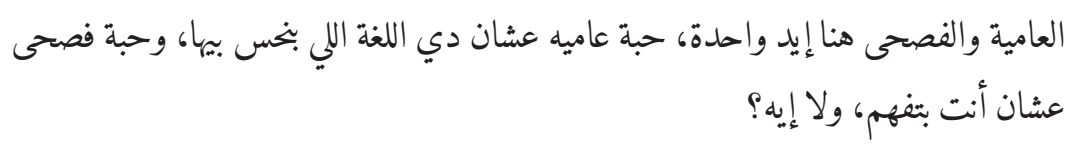

'àmmiyya and fuṣhā are here one hand, a bit of 'àmmiyya because that is the language that we feel in, and a bit of fuṣha because you understand, right?

AL-TĀBI'̄̄ 2012:6

$16 \bar{a}$ khir hăga, lit. transl. "last thing" is used as an intensifier carrying a strong meaning of "very". 25 refers to the January 25 th revolution, whereas "again and again" refers to that this is the second volume.

17 From the film السفارة في العمارة (The embassy is in the building).

18 la mu'ākhza translates "excuse me" or "pardon me", but has numerous usages, amongst them is in combination with, or instead of, a curse or something inappropriate.

19 The title plays on the dictionary published by the Language Academy, and perhaps تخليص (A Paris Profile) by Rifāa al-Ṭahțāwī. 
The play on the slogan from the 2011 uprisings signals that the reader should expect to find both varieties in the book. Except for three books that contain very little fus h $\bar{a}^{20}$ this is the case for most of the books. However, use of both varieties is done in different ways and with different amounts of the two varieties. Some are written predominately in one of the varieties, the other variety being inserted only a few places as lexical items, clauses or paragraphs.

\section{'Base' Varieties}

In some of these publications, the 'base' variety is 'ammmiyya, and fușhā occurs only occasionally. ${ }^{21} \mathrm{Al}$ - Isīli (2011:23) explains that maybe one third of his words are fuṣha, when he writes and perhaps also when he speaks:

When I use "فقط" (only) instead of "سبط" (only), this does not mean that I have saved (أنقذت "(أنقا) the Arabic language, nor that I am more cultured

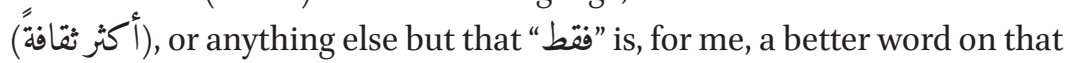
occasion (موضع), in that context ... or I use "س." because, for me, it is a

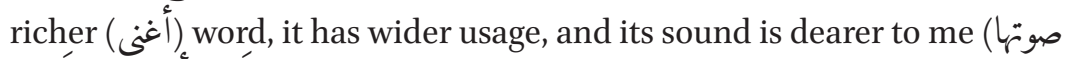

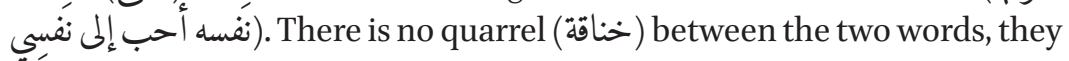
are both mine, and it is my right to use them both.

Al-Inkishārī (2012) also writes mainly in 'āmmiyya, but he uses fuṣhāa when presenting different types of lists, such as lists of hypotethical newspaper headlines and list of 'advice and wisdom'.

The opposite distribution is also found: basically writing in fușhā, but switching to 'àmmiyya at some occasions. ${ }^{22}$ In Ma'āṭi (2013), one finds 'āmmiyya in dialogues, but also occasionally in form of lexical items (or longer paragraphs of 'ammmiyya in an otherwise fușhā based text). Two recurring 'ammmiyya discourse markers in this book are بأه (so, then, however) and برضه (also, too).

In several parts of his book, Ḥasan (2011) uses fuṣhā as the base variety, as well as some 'unflagged' use of 'ämmiyya. There is, however, frequent use of 'flagged' (in parentheses) 'ammiyya, for example in an explanatory comment, such as the code-switching in the following example (Hasan 2011:40):

\footnotetext{
20 Nāgī (2013), Ahmad (2012b) and Ḥabīb (2013).

21 al-'Isīlī (2011), al-Inkishārī (2012) and al-Barbarī (2012).

22 Aḥmad (2012c), Macāṭī (2013).
} 


$$
\text { يعطيك المزيد من الميبة والوقار والضخامة (محدش هيحاول يتخانق معاك) }
$$

It gives you more awe, dignity and volume (no one will try to fight with you)

Most of Shuhayb's (2013) book consists of narrations about the happenings on January 25th 2011 and the following days. These narratives are mostly in fuṣhā, but there is occasional occurrence of an unambiguous EA item, e.g.:

$$
\text { فكرت في فتاة أحلامي اللي لم أقابلها بعد }
$$

I thought about the girl of my dreams, whom I have not met yet SHUHAYB 2013:43

\section{Code-Switching}

'Inter-sentential' or 'alternational code-switching' i.e. "switching between stretches of speech belonging to one and the other code/language/variety" (Mejdell 2006:414) occurs in several of the analyzed books. Rosenbaum (2012:299) describes a literary device where switching between the varieties "reflect the characters' speech or thoughts in their own language and style". He refers to this device as "changing the point of view through the use of CEA". In the examples Rosenbaum gives, 'ämmiyya represents the speech and thoughts of characters or protagonist narrators. This type of switching is found frequently in my corpus. However, in the following examples of codeswitching, 'ammmiyya does not represent a specific character's thoughts, but switching between the varieties appear to be a stylistic device emphasizing a sarcastic comment. In the first example, fuṣha (bold) mirrors a 'common saying' or advice, whereas 'āmmiyya (red) represents the author's sarcastic comment:

$$
\text { لا تترك والدتك تشاهد قنوات الطبخ .لأنها كده كده هتطبخ اللي بتعرف تعمله بس .. }
$$

Don't let your mother watch cooking channels ... because she will only cook what she knows anyways

GALĀL 2013:90

In the following example, fuṣha mirrors a 'common wisdom', which is interrupted and completed by the author's sarcastic comment in 'āmmiyya: 


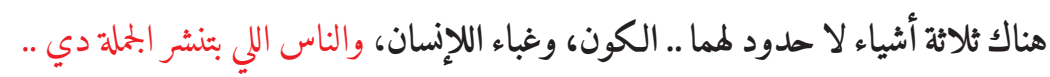

There are three things that have no limits ... the universe, human stupidity, and people who post that sentence ...

GALĀL 2013:94

The following example is from another book, and comes in a short chapter called "a call for understanding Egyptian 'ämmiyya", where some words and expressions in 'ammiyya are explained. The following is an example of a situation that can describe the word حمراة (diversion) where the passage in fuṣha evokes the style of a lexical entry explanation, followed by a switch to 'àmmiyya which again represents a sarcastic comment:

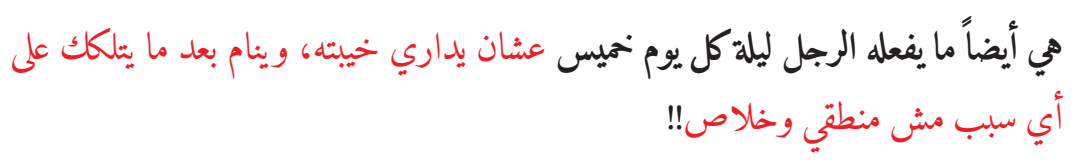

It is also what the man does every Thursday to hide his failure, and go to sleep after picking a fight about anything without logic!!

AL-TĀBI'Ī 2012:16

\section{Fuṣ̣āmmiyya}

Rosenbaum (2000) proposes the name Fuṣhāmmiyya for an "alternating style" found in Egyptian prose texts where the fuṣha and 'ammiyya varieties are used in an alternating manner. Fuṣhāmmiyya, is, according to Rosenbaum (2000:71) "the result of the intention of a certain writer to create a style whose constituents are taken from the two stocks, that of Fuṣhā and that of 'Āmmiyya, but is neither; rather, it is something else." According to Rosenbaum (2000:83), the fuṣhāa and 'àmmiyya elements enjoy equal status, and the use of 'ämmiyya is not "restricted to single words, mainly for naming realia". He claims that one of the aims of writing in such a style is to create humour (Rosenbaum 2000:81). The Fuṣhāmmiyya style as described by Rosenbaum can be found in some of the books in my study. The two varieties appear to be of equal importance in the text, as opposed to a base variety with insertions or borrowings from the other variety. It is also the clear intention of the writer, e.g.:23

\footnotetext{
23 Bold represents unambiguous fușhā, whereas red represents unambiguous 'àmmiyya.
} 


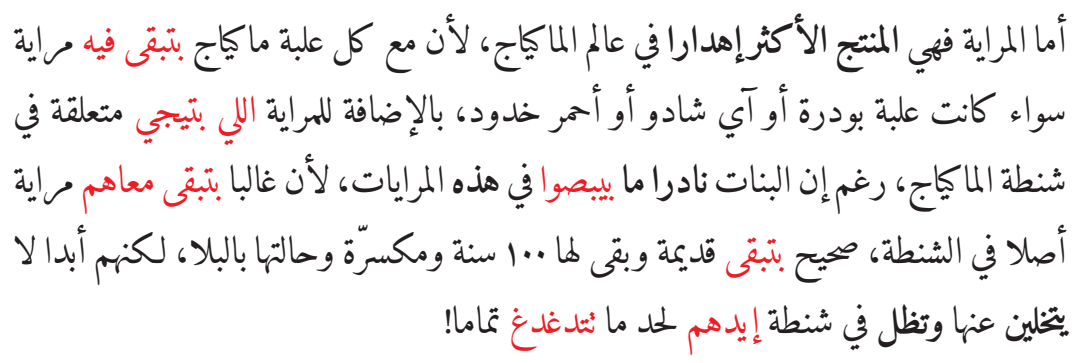

The mirror is the most wasted product in the make-up world, because in every make-up container, there is a mirror, no matter if it is powder, eye shadow or rouge, in addition to the mirror that comes with the make-up bag, even though girls rarely look in these mirrors. Because they usually have a mirror in their purse, right, it would be old, stayed in there for a hundred years, broken and messed up, but they never let go of it and it stays in their purses until it is totally crunched!

'ABD AL-WAHHĀB 2012:60

The style in this example is not a rarity in this book, but rather an example of the style in big parts of it, and it certainly contributes to leaving the boundaries between the varieties 'blurred' or 'fuzzy' (see Mejdell 2014, Mejdell Forthcoming-a, Mejdell Forthcoming-b).

\section{Word-Lists}

A phenomenon that is found in more than one of the adab sākhir books is a section where the author provides the readers with a list of words and expressions that are frequently used at the time the book is written. They are often neologisms and slang, sometimes belonging to the so-called 'youth language' (see Rizk 2007) or 'youth speech' (see Hassanein 2011).

'Abd al-Wahhāb (2012) says that her book is meant for the future generations. She explains present day phenomena that she thinks are likely to have changed or be outdated in 2050 , such as electronic devices and social network sites that were frequently used in 2012. The book also contains a section entitled "the dictionary". The author explains that "this dictionary is not only in order to log the most current words of our time, but in order for the new

I do not mark what can be read as either fuṣhā or 'āmmiyya (bivalent), or what is identical in both varieties (shared). 
generations to be able to read the book written in the language of our time" ('Abd al-Wahhāb 2012:34). The 'dictionary' is in alphabetical order and contains altogether 83 entries. They are stereotype descriptions of 'personalities', expression and lexical items with 'new meanings'. She provides examples of contexts in which they can occur, and it also contains explanations of short forms of prepositions and abbreviations typically used in computer mediated communication.

"Abd al-Wahhāb's second book (2013) has a "dictionary of insults" (قاموس)

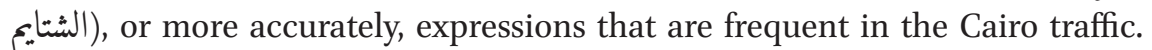
She divides the 'insults' into two groups; those girls hear while driving, most often from men, and those they might say themselves. Some examples from the first group are:

If you don't know how to drive, why do you ride a car?

I don't want to insult you because you are a woman

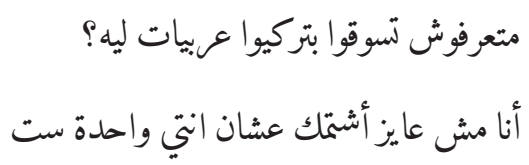

And from the second group:

You are the one making a mistake, by the way

Are you crazy?

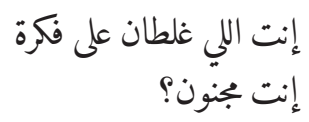

قاموس مصري فرنساوي (كلمنا Ahmad (2013) has a chapter called humorously (بالهجايص (Egyptian-French dictionary (brag to us)). The explanations of the words are not actually in French, but mostly in 'āmmiyya as well as some fuṣhā. He lists 18 words used by the Egyptian youth and gives a humorous explanation to each of them, some examples are: افتكاسة (silly innovation); الأنتخة (lazy sitting); ابرز (give what you have); ابجز (accomplish, complete); حور (talking empty talk); تيت (bleep); قلشة (quick funny comment); قلاش (someone who uses a lot of the previous).

In a book whose title is on the list of explained words above, namely تيييت (Bleep), Hasan (2011:107-124) explains different 'personalities' that have been named in the Egyptian 'ämmiyya. He provides the 'etymology' of the words,

24 Replaces a swearword or insult. 
and their current meaning. Some examples are: بلطجي ("Thug", from Turkish); بلط (بLazy”, from Coptic); بن الإيه ("Impressing”, from Coptic); باراشوت ("Pushy, intrusive", from French); نمرود ("Arrogant", from Coptic); مُونَّ ("Girl or attractive girl", from mezze).

Although the explanations of lexical items and expressions in the above mentioned books are interesting, the etymological explanations are not necessarily explanations that linguists would confirm. For example, Woidich (2006:95) notes that the word muzza derives from mazmazēl.

\section{Motivations for Use of 'āmmiyya or Mixing}

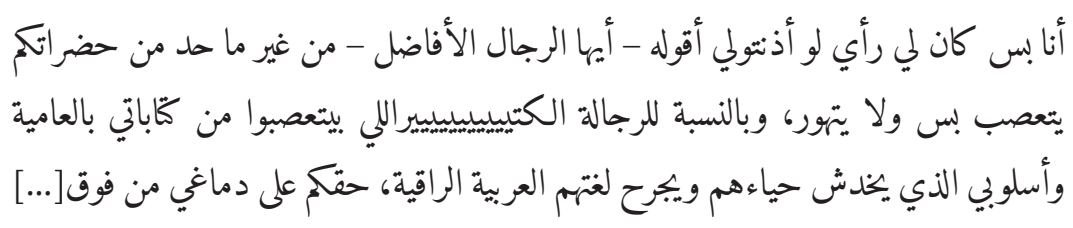

I just had a point of view if you would allow me to express it - you greatest among men - without any one of you getting angry or collapsing, and concerning the maaaany men who get angry with my writing in 'ämmiyya and my style that offends their morals and wounds their sophisticated Arabic language, I deeply apologize [...]

FĀRŪQ 2012:76

For texts written completely or partly in 'ammiyya, the linguistic choice is often mentioned and explained, or even apologized for in the introduction or elsewhere in the text (see Woidich 2010). These metalinguistic comments, together with statements made in interviews on television or other, provide some insight as to what motivates the authors' linguistic choices. In the following I present some of the motivations expressed by authors of adab sākhir books.

Shaymā' Habīb's book (2013) is written completely in 'ämmiyya, and she brings up her language choice in the very beginning of it. She sincerely admits that fușha is not her strongest side, and that she chose what appears to be an easier means for her to express herself (Habīb 2013:17):

This book is the first real experience for me, and to be honest, I was confused (محتارة) about which language to write in, so I decided that I will write the way I speak, or feel. In order to convey (أوصَّل what I want to 
in an easy and uncomplicated manner without lies ... I am not that good in fuṣhā

In a television interview, Habīb (13.12.2013) expresses that she writes in 'āmmiyya because she thinks in 'ammiyya, and she wants the readers to feel that she is talking directly to them, to delete the distance between reader and writer, so that the reader gets the sense of a conversation with a friend. As for the target group, the book was meant for university students as herself at the time the book was written. The fact that the book is written in 'ammiyya was, according to Habīb, criticized by literary advisors (mustashirin fi l-adab), but they would let it pass since this was her first writing experience. However, it would be preferable for her to write in fuṣhā in her next publication. From readers however, the feedback on her linguistic choice was very positive. Asked whether she had the impression that 'âmmiyya makes the book easier to understand, she replies that in general, not only with regard to language, the simpler (absat ) the easier (ashal).

Ahmad al-'Isili is perhaps one of the stronger contemporary defenders of writing in 'ämmiyya. In all three books he has published so far, he introduces the text by commenting on his choice of writing in 'ämmiyya. The following excerpt is from الكاب التاني, (al-'Isîlì 2011:22):

Firstly, I am more than fond of Egyptian 'ämmiyya because it is my mother language/tongue (لُعتي الأم) (not my dialect, no, my language, I really do consider it that), and secondly for its amazing richness, and thirdly, my emotional connection and complete control (تحكُُّ الكامل of it. And maybe more important than all of that: because I feel that it is mine ... and after all of that as well, because I feel it is more related than fuṣha , to this era of Egyptian writing and the type of writing (النوع من الكتابة) that I write, and to those who read me. And I want to be close to those who read me and listen to me, I want to reach them (عايز أوْصَلُّهُ) ...

Al-Isili's texts stand out from the others in that they have more vocalized words. He does not provide his readers with possible bivalent readings of the words, but signals clearly that e.g. صغيَّ (small) should be read șughayyar and not șaghir. He thinks that his writing style, using both ämmiyya and fuṣhā, although easier to write, may be challenging to read (al-Isiilì 2009:13). He encourages his readers to read according to the vocalization, "to read it like it is written, or in reality as it is 'said'" (al-Isilli 2011:9). In his latest book, he takes it a step further, saying that the book is an "audiobook", ("مساب "مسمو), and advices 
his readers to read it out loud, and it will be like hearing his voice (al-'Isìli 2015). This unusual request for the readers may be explained by al-'Isili profession as a television and radio presenter, and a wish to approach his reading 'audience' in the same language style that he approaches his tv and radio audience: his natural way of speaking.

Both Ḥabīb and al-'Isīli express that the use of 'ammmiyya lets them reach their readers more easily; it is a more direct means of communication, and it removes a distance between the writer and the readers. The same point is brought up by Muhammad Nāgī, author of the all-āmmiyya أشيك واد في شبرا (The chicest guy in Shubra), a book that is explicitly directed at readers in the age ranging from 17 to 30 . He says in a television interview that for him, it was more important for the message to reach out than to write the book in "al-lugha al-'arabiyya al-mu'aqqada" (the complex Arabic language) (Nāgī 07.02.2014). There is in other words a perception among the writers that the fuṣha variety does not reach the readers the same way as 'amminyya does, due to its complexity.

The 'complexity' of fuṣha may also be indexical of authority, something with which these writers do not want to be associated. They wish to speak to their peers in a familiar style indicating that they are on the same level, not in a style indexing them taking on an authoritarian role. Al-Tābi'î is interviewed concerning another of her books, also from the adab säkhir genre, and explains that she writes in 'ämmiyya (mixed with English expressions) because she wants to write in the language that is used, not to raise herself to the status of someone giving a lecture, debating or giving advice (al-Tābi'ī 16.o6.2014).

Shādī Aḥmad also discusses his writing in 'āmmiyya in a television interview, and points to the same motivations for writing in 'ammmiyya as seen above: it reaches the young readers, for whom the book is meant, in a simpler manner. The hosts put Ahmad on the spot, claiming that he is against fușhā, to which Ahmad responds that it is not a matter of being against, but a matter of a community that the youth has created to distinguish themselves from the parent-generation, and to which they have their own manner of speaking (lahga) and expressions (Ahmad 16.10.2013).

The perception among authors that when using ámmiyya, the message conveyed reaches the readers more easily is not unjustified; The survey "Language Change in Egypt: Social and Cultural Indicators Survey" (Kebede, Kindt and Høigilt 2013) reports that $76 \%$ of the respondents replied that they find it easier to understand things written in 'āmmiyya. Lubnā Imbārik (2013) is obvi- 
ously of the same impression, and raises the issue of people's lack of interest in reading in general. To increase people's interest in reading, she encourages the use of simple language (though not explicitly 'ämmiyya). She addresses those who set up school curriculums, requesting them to make it easier so that reading will be easier for the pupils, and not a matter of torment (تعذيب). Imbārik stresses the importance of reading and encourages parents to let their children be accustomed to reading from early age, and she asks the 'great' authors (الكتاب العظماء) to write books that are simple and easy (سهلة وبسيطة) (2013:24).

To sum up, by their own admission authors choose to write their adab sākhir in 'āmmiyya or a mix between 'ämminya and fuṣhā because they conceive of it as more familiar, easier to understand and better suited to reach the readers, who are predominately from the younger generation, in a more direct manner. They do not want to give the impression of being all-knowing and giving advice, and wish to avoid the authoritative index of fuṣhă.

\section{The 1st Person Narrative Mode}

Another common feature of the adab sākhir texts is that they are written from a first-person narrative perspective. This is the case for 20 out of the 21 adab sākhir books in my study: they are written either completely in the first-person narrative mode, or what appears to be switching between the first and third person. (It is however difficult to establish whether each instance of switching should in fact be regarded as switching or not, since first-person narration "almost invariably includes third-person narration" (Abbott 2008:71)). The one book that is written from a third-person narrative perspective, باط مان (Bat Man) (Hasîb 2012), follows the same language pattern as many of the novels and short stories, namely narratives in fuṣha and dialogues both in 'ämmiyya and in fuṣha . The genre of this book is also otherwise closer to that of the novel, in that it consists of one long fictional story.

As is claimed by Zack (2001) and (Woidich 2010), the first-person narrative, or the direct speech function, is found in most cases where the vernacular variety has been used in writing in Egypt. This goes for the vernacular in the early satirical newspapers that appeared in the forms of dialogues, the mudhakkirāt (Memoirs) literature that were written as monologues, and most novels that have been written in 'ammmiyya.

The phenomenon is, not surprisingly, not unique to the diglossic Arabic situation, but appears to be common in standard-with-dialects situations as well. Pointing to examples of use of Black English dialect in literature, Traugott 
(1981) shows that the dialect is only used in first person narrative. She claims that "[f]irst person narrative allows for a more subtle distinction between the narrative and the dialog because of the traditional connection between first person and colloquial style" (1981:312).

If a dialect or variety moves from being only used in direct speech in literature to be used in narratives from a third person narratives as well as nonliterary writing, it may become a new standard (Traugott 1981:313). Egyptian 'ammiyya certainly has the potential of becoming a new standard juxtaposed to fuṣha (see Woidich 2010), although there are strong forces to prevent that from happening. Rosenbaum argues that the Egyptian 'ämmiyya has come a long way on its path to becoming a literary language, and states (Rosenbaum 2011:338):

The rise and expansion of Egyptian Arabic as a literary language is a first case of its kind and a revolutionary change in the history of Arabic literature and culture in general, and in Egyptian culture in particular, a change which is still taking place right now.

\section{Genre Divide}

In my comparison of language pattern choices, the majority of the novels and short story collections are, as according to the norm, written in fușha in the narrative parts. The books classified as adab sākhir stand out, in that all except one contain 'ammmiyya in narrative sections. Interestingly, several of the authors who have written adab sākhir completely or partially in 'ämmiyya, have subsequently written novels (riwāya $\bar{a}$ ) where the narratives are in fuṣhā only. For instance, Shādī Aḥmad has written two other sākhir books in addition to the two already mentioned. ${ }^{25}$ They all contain great amounts of 'ammiyya, and have similar language style. However, in his novel كالتشيو (Calcio) (2015), Ahmad sticks to the dichotomy of fuṣha for the narrative sections and 'ammmiyya only in dialogues. According to Ahmad, ${ }^{26}$ "a novel has a different way of being written than satirical articles, something every writer has to respect". This attitude is reflected in Kebede, Kindt and Høigilt (2013), where $55 \%$ of the respondents considered 'àmmiyya 'not suitable' for novels.

25 Aḥmad (2012a, 2014).

26 Personal communication with the author on Facebook. 
The same change from writing in 'ämmiyya or a mix between 'ämmiyya and fuṣha in narratives in adab sākhir to narratives in fuṣha in a novel is seen with Muḥammad Nāgī 'Abdallāh ${ }^{27}$ (2016), and Jihād al-Tābi'ī (2016). Given that these writers first published adab sākhir and then turned to writing novels, one might read that the language reflects a development for them as creative writers. It may also be linked to the narrative mode and direct speech aspect: when writing adab sākhir in the first narrative mode, they address the readers directly, and they wish to do that in their 'personal' language which is closer to everyday language which is not associated with pedantry. Furthermore, the humour that is expected to be found in adab sākhir appears to be more easily expressed when the writer can use both varieties. However, the norm for language variety in the novel genre, and the writer's wish to become an 'acknowledged' writer is likely to play a role.

\section{Concluding Remarks}

Although adab sākhir has become a popular genre during the last ten years or more, and has received its own sections in bookstores, the genre is not new. The term adab sākhir was perhaps not coined until the 1980s, but although not labelled adab sākhir, satirical elements have a long history in Egyptian literature. Some of the adab sākhir of today does however receive criticism for not representing 'real' satire, with a 'correctional goal', solely focusing on humour for the purpose of entertaining, and there should perhaps be a different label for these.

Leading up to the 2011 revolution, adab sākhir was an arena where writers could direct criticism in a safe manner. Humour has always been characteristic of the Egyptian character, and jokes about former president Mubarak were composed and circulated during his thirty years in power. During the uprisings against his rule, however, humour in Egypt moved from the private to the public sphere, and from being "covert or indirect" to "direct and confrontational" (Anagondahalli and Khamis 2014:12). It took new forms and was seen everywhere: in slogans, songs, poetry, caricatures, picture manipulations, memes, graffiti etc., and was shared online in no time.

Use of 'ämmiyya is not a precondition for adab sākhir, but the genre does, however, seem to carry higher acceptance for use of ämmiyya or a mixed variety, as it is a genre that has extensive use of humorous elements such as irony, sarcasm and parody.

The writer only uses Muhammad Nāgī in his first publication. 


$$
\begin{aligned}
& \text { العامية مش مجرد لمجة، لأ، دي عصيرتراث وتاريخ مخلوط بظروف صعبة ومشاكل المصريين } \\
& \text { وفقرهم ومرضهم مع إضافة حبة عرق على شوية زحمة، واشرب يا معلم!! }
\end{aligned}
$$

'Ámmiyya is not only a dialect, no, it is the juice of heritage and history blended with hard circumstances and the Egyptians' problems, poverty and illness, along with some sweat and crowdedness. Drink up, ${ }^{28}$ boss!!

AL-TĀBI'ī 2012:17

\section{References}

\section{Primary Sources}

'Abd al-Wahhāb, 'Abīr. 2012. الحب في زمن الكارينا. Al-Qāhira: Dār al-Maṣrī.

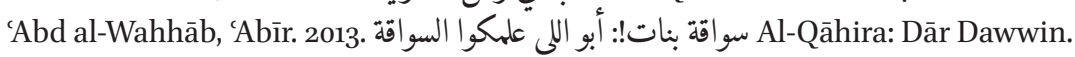

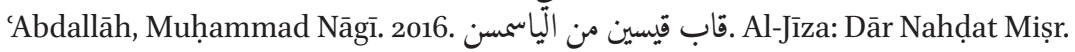
'Ādil, Dīnā. 2012. ولاد البطة السودا. Al-Qāhira: Šabāb Books. Ahmad, Shādī. 2012a. بابا سوبرمان. Al-Qāhira: Dār 'Uktub. Ahmad, Shādī. 2013. مصر لا مؤاخذة المانة. Al-Qāhira: Dār Nūn. Ahmad, Shādī. 2014. المدام. Al-Qāhira: Dār al-Mașrī. Ahmad, Shādī. 2015. Al-Qāhira: Dār Nūn. Ahmad, Shādī 2012b. العريس في رحلة البحث عن عروسة. Al-Qāhira: Dār al-Maṣrī. Ahmad, Tāmir. 2012c. دراعً مرسي: Spark Books.

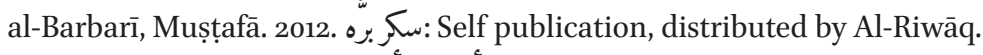
al-Inkishārī, 'Amr. 2012. أنا حقا أعترض. Al-Qāhira: Šabāb Books.

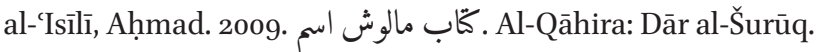
al-Isīili, Ahmmad. 2011. الكّاب التانيم. Al-Qāhira: Dār al-Šurūq. al-Isiilī, Ahmad. 2015. نص بكّاب . Al-Qāhira: Dār al-Šurūq.

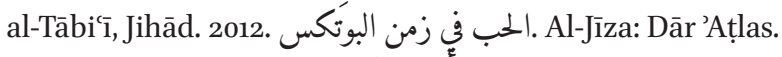

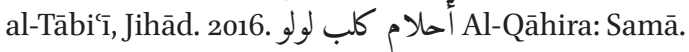

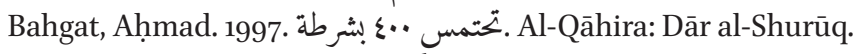
Bahgat, Ahmad. 2009. مذكرات زوطة Al-Qāhira: Dār al-Šurūq.

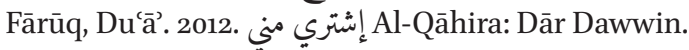
Galāl, Muhammad." 2013. الخّاب الأصفر: محاولة للف السرايا الصفرا في ورقة بفرة. Al-Jīza: Dār 'Ațlas.

Ḥabīb, Shaymā̄. 2013. المعجم الوجيز في تلخيص البهاريز. Al-Qāhira: Dār al-Mașrī. Ḥasan, Muhammad. 2011. تيييت. Al-Jìza: Al-Riwāq. 
Ḥasīb, Maḥmūd. 2012. Al-Jīza: Al-Riwāq.

Imbārik, Lubnā. 2013. طاجن تورلي بالمحمة. Al-Jīza: Dār 'Ațlas.

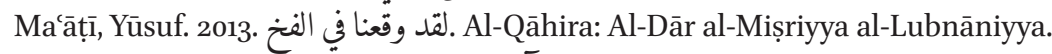

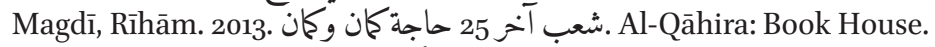

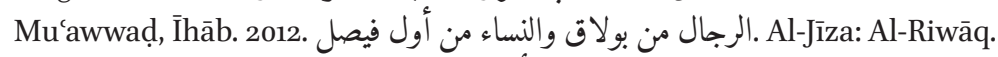

Nāgī, Muḥammad. 2013. أشيك واد في شبرا. Al-Qāhira: Dār 'Ibdāc.

Shuhayb, Muștafā 2013. خيمة. Al-Jīza: Al-Riwāq.

\section{Secondary Sources}

Abbott, H. Porter. 2008. The Cambridge Introduction to Narrative. Cambridge: Cambridge University Press.

al-Shirbīn̄i, Yūsuf ibn Muḥammad and Humphrey Davies. 2005. Yūsuf Al-Shirbìnìs Kitāb Hazz Al-Quhūf Bi-Sharh Qașìd Abī Shādūf: Brains Confounded by the Ode of Abū Shādūf Expounded, Volume I: Arabic Text, Vol. 141. Leuven: Peeters.

Anagondahalli, Deepa and Sahar Khamis. 2014. "Mubarak Framed! Humor and Political Activism before and During the Egyptian Revolution." Arab Media and Society (19):116.

Badawi, El-Said and Martin Hinds. 1986. "A Dictionary of Egyptian Arabic". Beirut: Librarie du Liban.

Davies, Humphrey. 1981. "Seventeenth-Century Egyptian Arabic. A Profile of the Colloquial Material in Yūsuf Al-Shirbīnīs Kitāb Hazz Al-Quhūf Bi-Sharḥ Qaṣīd Abī Shādūf" PhD, University of California, Berkeley.

Davies, Humphrey. 200o. "Yusuf Al-Shirbini's "Hazz Al-Quhuf": Issues Relevant to Its Assessment as a Source for 17th Century Egyptian Colloquial." Al-Logha (2):57-78.

Doss, Madiha and Humphrey Davies. 2013. العامية المصرية المكتوبة. Al-Qāhira: Al-Hay’a alMișriyya al-'Āmma lil-Kitāb.

Elliott, Robert C. 2007. "Satire." (https://global.britannica.com/art/satire).

Elsadda, Hoda. 2010. "Arab Women Bloggers: The Emergence of Literary Counterpublics." Middle East Journal of Culture and Communication (3):312-332.

Fahmy, Ziad. 2011. Ordinary Egyptians: Creating the Modern Nation through Popular Culture. Stanford: Stanford University Press.

Guth, Stephan. 2017 Forthcoming. "Progams of Renewal - Towards an 'adab Al-Bawh Wa'l-Sidq Wa'l Karāmah? An Analytical and Comparative Glance at the Forewords of Some Recent (Literary?) Publications." in Scheduled for the Proceedings of the nth Euramal Conference on New Geographies and Genres: The Function of Literature, Held May 7-10, 2014 in Madrid, edited by G. F. Parilla.

Hassanein, Ahmad Taher. 2011. "Youth Speech." in Encyclopedia of Arabic Language and Linguistics, edited by L. Edzard and R. De Jong. Brill Online: Brill.

Jacquemond, Richard. 2008. Conscience of the Nation: Writers, State, and Society in Modern Egypt. Translated by D. Tresilian. Cairo: American University in Cairo Press. 
Jacquemond, Richard. 2016. "Satiric Literature and Other "Popular" Literary Genres in Egypt Today." Journal of Arabic and Islamic Studies 16:349-367.

Kebede, Tewodros Aragie, Kristian Takvam Kindt and Jacob Høigilt. 2013. "Language Change in Egypt: Social and Cultural Indicators Survey - a Tabulation Report." Vol. 39. Fafo.

Mejdell, Gunvor. 2006. "Code-Switching." Pp. 414-421 in Encyclopedia of Arabic Language and Linguistics, Vol. 1, edited by K. Versteegh. Leiden-Boston: Brill.

Mejdell, Gunvor. 2014. "Strategic Bivalency in Written 'Mixed Style'? A Reading of Ibrahīm 'Īsā in Al-Dustūr." Pp. 273-278 in Alf Lahga Wa Lahga: Proceedings of the gth Aida Conference, edited by O. Durand, A. D. Langone and G. Mion. Münster: Lit Verlag.

Mejdell, Gunvor. Forthcoming-a. "Entangled Pyramids and Rainbows - on Challenging the Divide in a Written Mixed Text."

Mejdell, Gunvor. Forthcoming-b. "Erasing Boundaries in Contemporary Written Mixed Arabic (Egypt)."

Rāghib, Nabīl. 2000. الأدب الساخر. Al-Qāhira: Al-Hay’a al-Mișriyya al-Āmma lil-Kitāb.

Rizk, Sherin. 2007. "The Language of Cairo's Young University Students." Pp. 291-308 in Arabic in the city: Issues in dialect contact and language variation, edited by C. Miller, E. Al-Wer, D. Caubet and J. C. E. Watson. London: Routledge.

Rosenbaum, Gabriel M. 2000. "Fuṣhammiyya: Alternating Style in Egyptian Prose." Journal of Arabic Linguistics (38):68-87.

Rosenbaum, Gabriel M. 2011. "The Rise and Expansion of Colloquial Egyptian Arabic as a Literary Language." Pp. 323-343 in Culture Contacts and the Making of Cultures. Papers in Homage to Itamar Even-Zohar edited by R. Sela-Sheffy and G. Toury. Tel Aviv: Tel Aviv University: Unit of Culture Research.

Rosenbaum, Gabriel M. 2012. "Mixed Arabic and Stylistic Choices in Contemporary Egyptian Writing." Pp. 291-306 in Au-Delà De L'arabe Standard: Moyen Arabe Et Arabe Mixte Dans Les Sources Médiévales, Modernes Et Contemporaines, Vol. 28, Quaderni Di Semitistica, edited by L. Bettini and P. La Spisa. Firenze: Dipartimento di scienze dell'antichità, Medioevo e Rinascimento e linguistica, Università di Firenze.

Traugott, Elizabeth Closs. 1981. "The Sociostylistics of Minority Dialect in Literary Prose." Pp. 308-316 in Annual Meeting of the Berkeley Linguistics Society, Vol. 7. van Gelder, G. J. H. 1998. "Satire, Medieval." Pp. 693-695 in Encyclopedia of Arabic Literature, Vol. 2, edited by J. S. Meisami and P. Starkey. London: Routledge.

Woidich, Manfred. 2006. Das Kairenisch-Arabische: Eine Grammatik. Wiesbaden: Harrassowitz.

Woidich, Manfred. 2010. "Von Der Wörtlichen Rede Zur Sachprosa: Zur Entwicklung Der Ägyptisch-Arabischen Dialektliteratur." in Forschungskolloquium am Interdisziplinären Zentrum für Dialektforschung an der Friedrich-Alexander-Universität Erlan- 
gen-Nürnberg, 19.11.2009-20.11.2009, edited by H. H. Munske. Friedrich-AlexanderUniversität Erlangen-Nürnberg.

Zack, Elisabeth. 2001. "The Use of Colloquial Arabic in Prose Literature: "Laban Il’așfūr" by Yūsuf Al-Qa'īd”. Quaderni di Studi Arabi 19:193-219.

Zack, Liesbeth. 2014. "The Use of the Egyptian Dialect in the Satirical Newspaper Abu Naḍ̂ara Zar'a." Pp. 465-478 in Alf Lahga Wa Lahga Proceedings of the gth Aida Conference, edited by O. Durand, A. D. Langone and G. Mion. Münster: Lit Verlag.

\section{Television Interviews}

Aḥmad, Shādī. 16.10.2013. in Bukra līnā. Honest Tv: https://www.youtube.com/watch?v $=\mathrm{ij} 2 \mathrm{aOWCX} 7 \mathrm{As}$ Last accessed 30.01.2017.

al-Tābi'ī, Jihād. 16.o6.2014. in 'Izz al-shabāb. Rotana Masriya: https://www.youtube .com/watch?v=m6SvHWcq_Ys Last accessed 30.01.2017.

Ḥabīb, Shaymā'. 13.12.2013. in Shabāb 'alā al-hawā. Nile Family: https://www.youtube .com/watch?v=5ReHD8YwomY Last accessed 30.01.2017.

Mu'awwaḍ, İhāb. 02.09.2014. in Sitt al-ḥusn. onTv: https://www.youtube.com/watch?v $=\mathrm{iA6MMStGwTk}$ Last accessed 30.01.2017.

Nāgī, Muḥammad. 07.02.2014. in Nahārak saìd. Nile Life: https://www.youtube.com/ watch?v=KH3 TpxAHTIc Last accessed 30.01.2017.

\section{Online Articles}

14.11.2010. “" "كّاب الأدب الساخر في مصر .. بين مؤيد ومعارض." in Buṣs wi tull. http://boswtol .com/culture/culture-followup/10/November/14/145476 Retreived 04.09.2014.

Lu’ay, Riḥāb. 18.10.2009، "الكخابة الساخرة في مصر سماجة واستظراف/", masress.com: Rūz al-Yūsuf. http://www.masress.com/rosadaily/24137 Retreived 04.09.2014. 